\title{
BIO-EKOLOGI IKAN UCENG (Nemacheilus fasciatus) DI KALI LEKSO, BLITAR
}

\author{
Didik Wahju Hendro Tjahjo*', Sri Endah Purnamaningtyas", dan Kunto Purnomo"'
}

\begin{abstract}
ABSTRAK
Penelitian bio-ekologi ikan uceng (Nemacheilus fasciatus) di Kali Lekso telah dilakukan, meliputi aspek biologi populasi ikan uceng dan ekosistem perairan dengan metode survai dengan pengambilan sampel strata. Ikan uceng $(2,12-5,55 \mathrm{~g})$ mempunyai fekunditas total berkisar 2.257 1.3760 butir telur. Pola sebaran diameter telur menunjukkan bahwa pemijahan terjadi sekali dalam satu tahun (musim) dengan lama waktu pemijahan relatif panjang. Secara umum kualitas air di Kali Lekso cukup mendukung bagi kehidupan ikan dan organisme pakannya. Organisme produsen yang ada di Kali L.ekso merupakan organisme perifiton termasuk genus Chaetophora, Fragillaria, Surirella, Navicula dan Zygnema. Zoobentos di perairan ini didominasi oleh larva caddisfly (Trichoptera). Hasil analisis isi perut ikan menunjukkan ikan uceng, paray (Rasbora argyrotaenia), wader (Puntius binotatus), tapelwatu (Glyptothorax platypogon), dan kutuk (Channa gachua) termasuk predator. Empat jenis ikan karnivora tersebut bersifat spesialis dan mempunyai pakan utama yang sama, sehingga berpeluang terjadinya kompetisi yang tinggi. Secara umum, kualitas air di Kali Lekso cukup mendukung kehidupan ikan dan organisme pakannya
\end{abstract}

ABSTRACT: Eco-biology of uceng (Nemacheilus fasciatus) in Lekso Stream, Blitar. By: Didik Wahju Hendro Tjahjo, Sri Endah Purnamaningtyas, and Kunto Purnomo

A study on eco-biology of uceng (Nemacheilus fasciatus) in Lekso Stream including aspects of the biological population of uceng and the ecosystem has been carried out using survey method with stratified sampling. Uceng (2.12-5.55 g) had absolute fecundities ranging 2,25713,780 eggs. Based on the egg distribution pattern, it was shown that the fish spawned once a year with prolonged time. Generally, water qualities of Lekso steam support the lives of fishes and food organisms in Lekso Stream. The producer organism was periphyton such as: Chaetophora Fragillaria, Surirella, Navicula, dan Zygnema. The zoobenthics was dominated by caddisfly larva (Trichoptera). Results of stomach content observation showed that uceng, paray (Rasbora argyrotaenia), wader (Puntius binotatus) and tapelwatu (Glyptothorax platypogon) were carnivorus fishes, and kutuk (Channa gachua) was a predator. These four carnivorous fish species had the same specific food consumption pattern and the same primary food, potential food competitions to each other. Generally, water quality of Stream Lekso was good enough for supporting the life of uceng and food organisms.

KEY WORDS: uceng, fish biology, ecology of Lekso Stream

\section{PENDAHULUAN}

Kali Lekso merupakan anak Sungai Brantas yang terletak di Kecamatan Wlingi, Kabupaten Blitar. Panjang aliran sungai ini mencapai $25 \mathrm{~km}$ dengan sumber air di lereng Gunung Kelud. Daerah aliran sungainya sebagian besar merupakan daerah pesawahan dan perkebunan.

Salah satu pemanfaatan sumber daya sungai ini adalah perikanan tangkap dengan jenis ikan utamanya uceng (Nemacheilus fasciatus), dan jenis ikan lainnya adalah kutuk atau gabus gunung (Channa gachua), lele (Clarias batrachus), paray (Rasbora argyrotaenia), wader (Puntius binotatus), tapelwatu (Glyptothorax platypogon), belut (Monopterus albus), kepala timah (Poecilia reticulata) dan udang kali (Macrobrachium sp.). Pada saat ini, Pemerintah Daerah Dati II Blitar baru gencar-gencarnya mempromosikan ikan uceng sebagai makanan khas Blitar, seperti layaknya ikan bilih bagi Sumatera Barat. Dengan demikian, kegiatan penangkapan ikan tersebut dilakukan sangat intensif. Diperkirakan produksi ikan uceng ini berkisar 20-60 $\mathrm{kg} / \mathrm{hari}$ atau 5-15 ton/tahun dengan asumsi penangkapan hanya dilakukan 250 hari/tahun

Kelestarian produksi ikan tersebut terancam, karena kegiatan penangkapan ikan tersebut dilakukan dengan menggunakan alat tangkap yang tidak ramah lingkungan (alat tangkap dengan menggunakan listrik). Di samping itu, kegiatan yang merusak habitatnya melalui penambangan batu-kali semakin meningkat, sedangkan aspek bio-ekologi ikan tersebut belum banyak diketahui. Oleh karena itu, tujuan dari penelitian ini adalah untuk mengetahui aspek biologi populasi ikan uceng dan ekosistem perairan Kali Lekso. Hasil

*) Peneliti pada Balai Penelitian Perikanan Air Tawar 
penelitian ini diharapkan dapat digunakan sebagai informasi dalam mengelola sumber daya Kali Lekso, khususnya populasi ikan uceng.

\section{BAHAN DAN METODE}

\section{Lokasi dan Pengambilan Contoh}

Penelitian ini dilakukan di Kali Lekso Kabupaten Blitar. Pengamatan dilakukan tiga kali selama tahun 1996, yaitu pada musim peralihan (Juli), musim kemarau (September), dan musim hujan (November).

Metode yang dipakai dalam penelitian ini adalah metode survai dengan pengambilan sampel strata (Parel et al., 1973). Sedangkan penentuan stasiun pengamatan berdasarkan kecepatan arus air dan tingkat pemanfaatan perairan tersebut (penambangan batu-kali), seperti tertera pada Gambar 1. Pada masing-masing stasiun dilakukan pengamatan terhadap kualitas lingkungan serta karakteristik populasi ikan. Variabel kualitas perairan yang diamati meliputi suhu air, $\mathrm{pH}$, alkalinitas, $\mathrm{CO}_{2}, \mathrm{O}_{2}, \mathrm{~N}-\mathrm{NO}_{2}, \mathrm{~N}$ $\mathrm{NO}_{3}, \mathrm{~N}-\mathrm{NH}_{4}, \mathrm{~S}-\mathrm{SO}_{4}, \mathrm{P}-\mathrm{PO}_{4}, \mathrm{Ca}, \mathrm{Mg}$, dan bahan organik total, serta metode yang digunakan dalam analisis kualitas air tertera pada Tabel 1. Penangkapan ikan dilakukan pada area seluas $40 \mathrm{~m}^{2}$ (panjang $=40 \mathrm{~m}$ dan lebar $=1 \mathrm{~m}$ ) untuk masing-masing stasiun pengamatan

Aspek bio-ekologi ikan uceng di kali Lekso yang diamati meliputi 2 aspek utama, yaitu: aspek biologi populasi ikan uceng dan aspek ekologi Kali Lekso. Aspek biologi ikan uceng meliputi: pola pergerakan, reproduksi, dan pola rekruitmen. Aspek ekologi Kali Lekso meliputi: kualitas perairan, jenis ikan, keragaman jenis, komposisi ikan, kebiasaan makan, tingkat trofik dan luas relung pakannya

\section{Analisis Data}

\section{Aspek biologi ikan uceng}

Reproduksi ikan uceng meliputi fekunditas total dihitung dengan menggunakan metode gravimetrik dan formulasi sebagai berikut:

$$
N=(G / g) n
$$

dengan:

$\mathrm{N}=$ fekunditas total

$\mathrm{G}=$ bobot gonad total

$\mathrm{g}=$ bobot gonad sampel

$\mathrm{n}=$ jumlah telur dari gonad sample.

Sebaran diameter telur dikelompokkan dengan menggunakan modal progression analysis dari Bhattacharya dalam program FiSAT(Gayalino, 1987) Pola sebaran diameter telur kemudian digunakan untuk menganalisis pola pemijahan ikan tersebut.

Analisis pola gerakan ikan uceng didasarkan pada perubahan komposisi kelompok ukuran untuk masingmasing stasiun dan waktu pengamatan. Sedangkan pengelompokan ukuran ikan dihitung berdasarkan ukuran panjang total dengan menggunakan modal progression analysis dari Bhattacharya dalam FiSAT dan selanjutnya diplot menurut stasiun dan waktu pengamatan.

Tabel 1. Metode atau alat yang digunakan dalam pengamatan peubah kualitas air di Kali Lekso Table 1. Method or tools used for observation of water qualitiy variables in Lekso Stream

\begin{tabular}{|c|c|c|}
\hline $\begin{array}{c}\text { Peubah kualitas air } \\
\text { Water qualities variable }\end{array}$ & $\begin{array}{l}\text { Satuan } \\
\text { Unit }\end{array}$ & $\begin{array}{l}\text { Metode a tau alat } \\
\text { Method or tools }\end{array}$ \\
\hline Suhu air/Water temperature & ${ }^{\circ} \mathrm{C}$ & Termometer/Thermometer \\
\hline $\mathrm{pH}$ & Unit $\mathrm{pH}$ & $\mathrm{pH}$ indicatorlindikator $\mathrm{pH}$ \\
\hline $\mathrm{CO}_{2}$ & $\mathrm{mg} / \mathrm{L} \mathrm{CaCO}_{3} \mathrm{eq}$ & Titration/Titrasi \\
\hline $\mathrm{O}_{21}$ & $\mathrm{mg} / \mathrm{L}$ & Titration/Titrasi \\
\hline $\mathrm{N}-\mathrm{NO}_{2}$ & $\mathrm{mg} / \mathrm{L}$ & Titration/Titrasi \\
\hline $\mathrm{N}-\mathrm{NO}_{3}$ & $\mathrm{mg} / \mathrm{L}$ & Spektrofotometer/Spectrophotometer \\
\hline $\mathrm{N}-\mathrm{NH}_{4}$ & $\mathrm{mg} / \mathrm{L}$ & Spektrofotometer/Spectrophotometer \\
\hline $\mathrm{S}-\mathrm{SO}_{4}$ & $\mathrm{mg} / \mathrm{L}$ & Spektrofotometer/Spectrophotometer \\
\hline $\mathrm{P}-\mathrm{PO}_{41}$ & $\mathrm{mg} / \mathrm{L}$ & Spektrofotometer/Spectrophotometer \\
\hline $\mathrm{Ca}_{1}$ & $\mathrm{mg} / \mathrm{L} \mathrm{CaCO}_{3} \mathrm{eq}$ & Titration/Titrasi \\
\hline $\mathrm{Mg}$ & $\mathrm{mg} / \mathrm{L} \mathrm{CaCO} \mathrm{Ca}_{3} \mathrm{eq}$ & Titration/Titrasi \\
\hline $\begin{array}{l}\text { Bahan organik total } \\
\text { Total organic matter }\end{array}$ & $\mathrm{mg} / \mathrm{L}$ & Titration/Titrasi \\
\hline
\end{tabular}




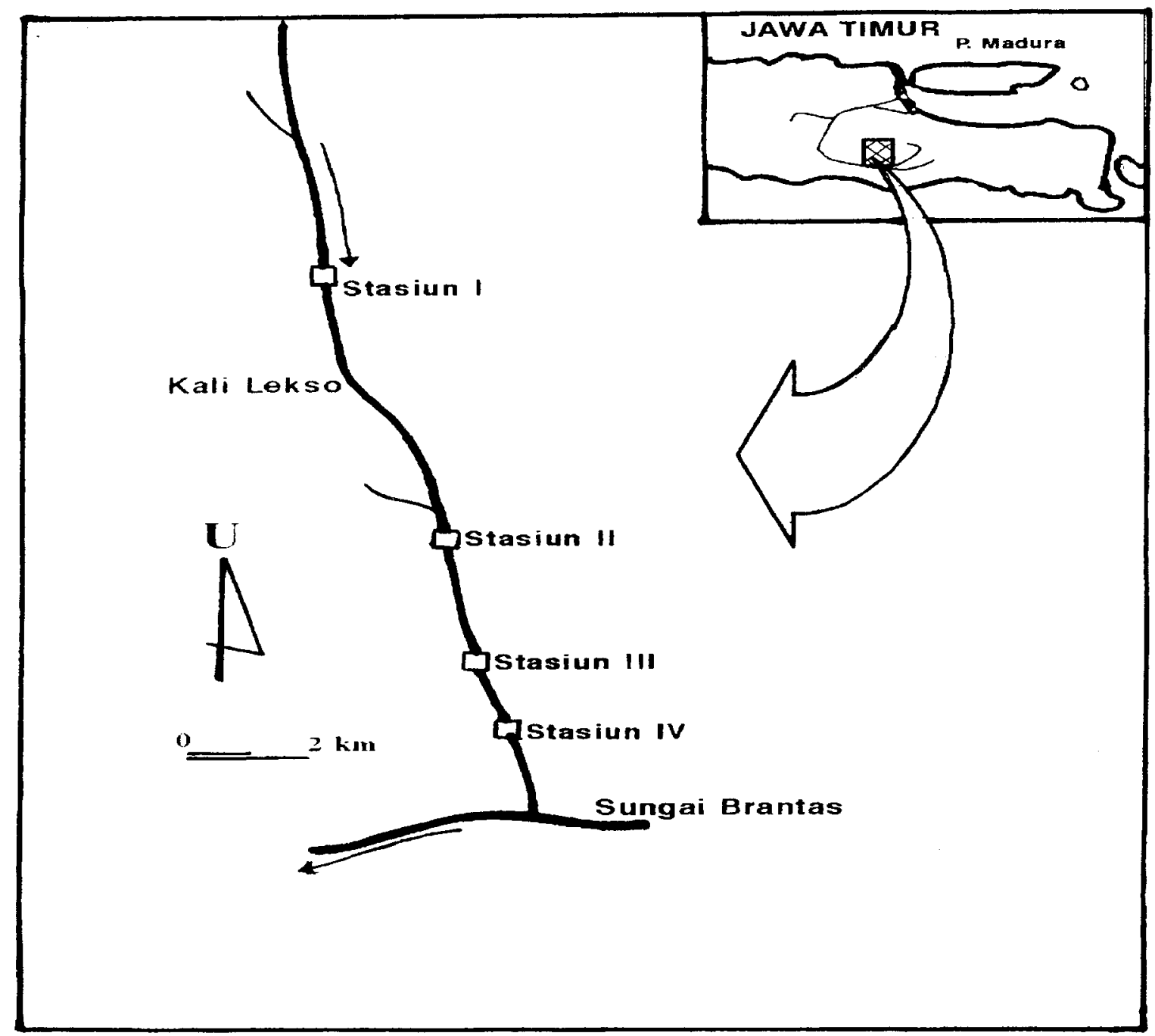

Gambar 1. Lokasi stasiun pengamatan di Kali Lekso, Jawa Timur

Figure 1. Location of sampling station in Lekso Stream, East Java

\section{Aspek ekologi Kali Lekso}

Analisis keragaman ikan didasarkan pada Indeks Keragaman Shannon-Wienner (Magurran, 1988) dan distribusi kelimpahan Motomura (Amanieu, 1981). Rumus keragaman yang digunakan adalah:

$$
D=p_{i} \log _{2} p_{i} \quad q_{i}=q_{1} m^{(s-1)}
$$

dengan:

$D=$ keragaman

$p_{i}=$ proporsional kelimpahan jenis ikan ke-i

$q_{i}=$ kelimpahan relatif untuk jenis ikan ke-i

$\mathrm{m}=$ konstanta Motomura, dan $\mathrm{s}=$ peringkat dari jenis ikan ke-i.

Kebiasaan makan dianalisis dengan menggunakan metode indeks preponderan (Natarajan \& Jhingran (1961) dalam Effendie, 1979), yaitu:

$$
I_{i}=\left(V_{i} O_{i}\right) /\left\{O ́\left(V_{i} O_{i}\right)\right\}
$$

dengan:

$I_{i}=$ indeks preponderan pakan $k e-i$

$V_{1}=$ persentase volume pakan $k e-i$

$\mathrm{O}_{\mathrm{i}}=$ persentase kejadian pakan ke-i.

Perhitungan tingkat trofik didasarkan pada hubungan tingkat trofik organisme pakan dan kebiasaan pakan yuwana ikan tersebut (Mearns et al. (1981) dalam Caddy dan Sharp, 1986), dengan rumus:

$$
T_{p}=1+O\left\{\left(T_{t p}{ }_{p}\right) / 100\right\}
$$

dengan:

$T_{p}=$ tingkat trofik ikan

$\mathrm{T}_{\mathrm{p}}^{\mathrm{p}}=$ tingkat trofik kelompok pakan ke-p

$I_{p}=$ indeks preponderan ikan untuk kelompok pakan ke-p. 
Luas relung pakan dianalisis dengan menggunakan Indeks Levin yang didasarkan pada informasi data kebiasaan makan (Hespenheide, 1975) sebagai berikut:

$$
B=\left(O p_{i}^{2}\right)^{-1}
$$

dengan

$B=$ luas relung makan

$\mathrm{p}_{\mathrm{i}}=$ proporsional jenis pakan ke-i yang dikonsumsi.

Semua data dianalisis dengan menggunakan Quatro Pro dan Statgraphics.

\section{HASIL DAN BAHASAN}

\section{Biologi Ikan Uceng}

Fekunditas total ikan uceng yang berukuran panjang antara $6,0-8,0 \mathrm{~cm}$ dengan bobot antara 2,12 $5,55 \mathrm{~g}$ ( $\mathrm{n}=41$ ekor) berkisar antara $2.257-13.760$ butir telur. Hubungan antara bobot ikan dengan fekunditas total menunjukkan kecenderungan fekunditas total meningkat seiring dengan peningkatan bobot ikan tersebut (Gambar 2). Diameter telur ikan ini pada

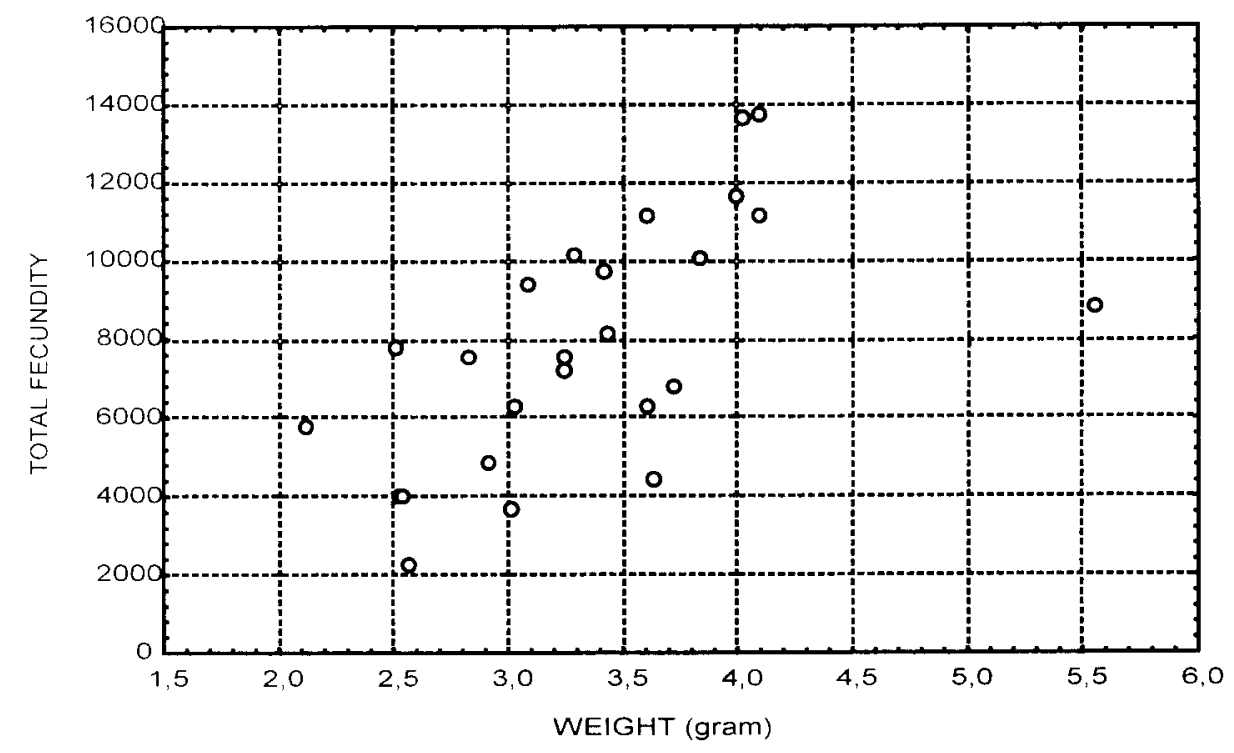

Gambar 2. Hubungan bobot (g) dengan fekunditas total (butir telur) ikan uceng di Kali Lekso Figure 2. Relationship between weight ( $g$ ) and total fecundity of uceng in Lekso Stream

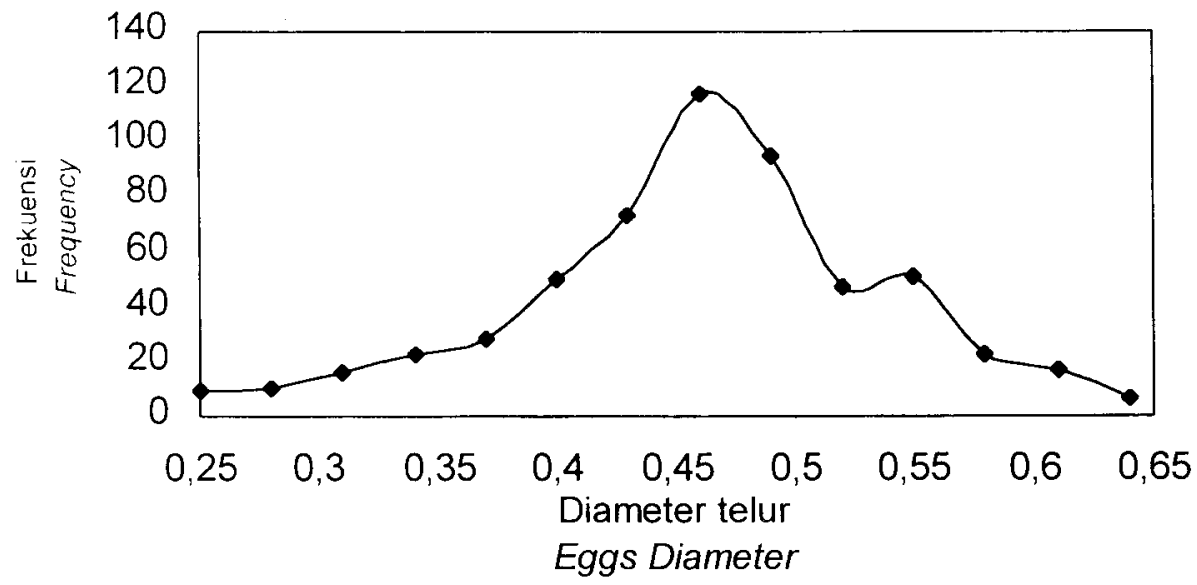

Gambar 3. Sebaran diameter telur ikan uceng

Figure 3. Distribution of egg diameter of uceng ( $N$. fasciatus) 
tingkat kematangan gonad IV berkisar antara 0,25$0,64 \mathrm{~mm}$. Berdasarkan pola sebaran diameter telurnya, pola rekrutmen stok ikan uceng menunjukkan puncak tunggal (Gambar 3). Hal tersebut berarti ikan ini melakukan pemijahan sekali dalam satu tahun (musim) dengan lama waktu pemijahan relatif panjang

Dalam kehidupan dan perkembangannya, jenis ikan pada umumnya selalu melakukan gerakan menuju daerah pakan atau daerah pemijahan. Pada bulan Juli (musim pancaroba) sebanyak 8,9\% (27 ekor dari 305 ekor) jumlah ikan uceng yang tertangkap telah matang gonad. Dari jumiah ikan tersebut $74,1 \%$ ter- tangkap di bagian hulu sungai (stasiun pengamatan II). Pada bulan September (musim kemarau) jumlah ikan uceng yang matang gonad hanya 4,4 \% (14 ekor dari 317 ekor), dan $85,7 \%$ di antaranya ada di daerah hulu (stasiun pengamatan I dan II). Di samping itu, di daerah hulu tersebut banyak ditemukan ikan uceng yang berukuran kecil.

Sedangkan pada bulan November (musim hujan) ada suatu pergerakan di mana ikan uceng yang berukuran besar mulai banyak ditemukan di bagian hulu sungai, dan sebaliknya anak-anaknya (yuwana) mulai bergerak ke bagian hilir sungai (Gambar 4).

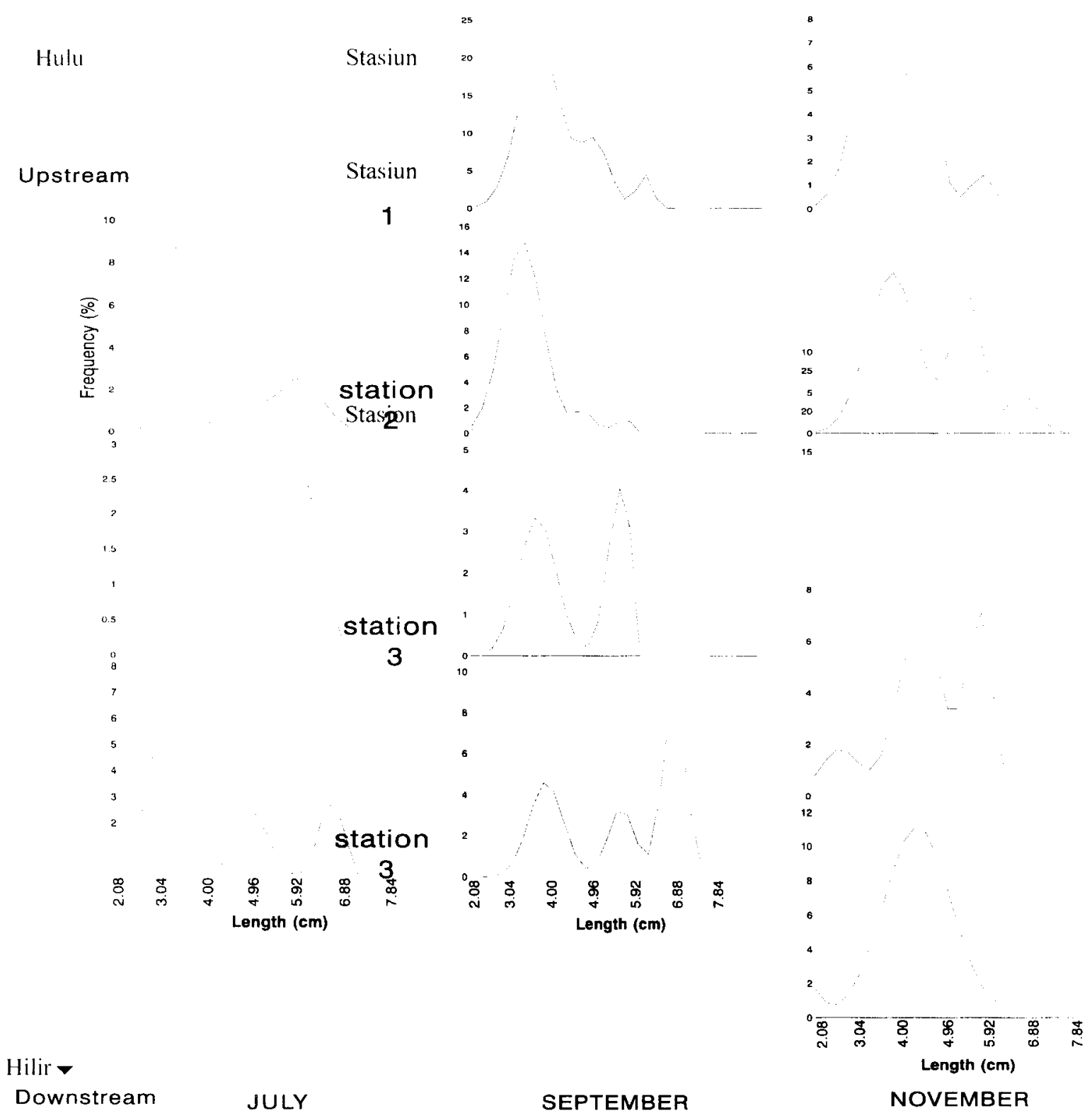

Gambar 4. Frekuensi panjang total ikan uceng menurut stasiun dan waktu pengamatan

Figure 4. Length frequency distribution of uceng to stations and time of observation 
Tabel 2. Kualitas air Kali Lekso, Blitar

Table 2. Water quality on Lekso Stream, Blitar

\begin{tabular}{|c|c|c|c|c|}
\hline \multirow{2}{*}{$\begin{array}{l}\text { Parameter kualitas air } \\
\text { Variable of water quality }\end{array}$} & \multicolumn{4}{|c|}{$\begin{array}{l}\text { Stasion } \\
\text { Station }\end{array}$} \\
\hline & 1 & II & III & IV \\
\hline Suhu/Temperature $\left({ }^{0} \mathrm{C}\right)$ & 26.0 & 26.0 & 25.5 & 26.0 \\
\hline $\mathrm{pH}$ (unit $\mathrm{pH})$ & 8.3 & 8.2 & 8.6 & 8.5 \\
\hline Alkalinitas/alkalinity (mg/L) & 2.7 & 2.8 & 2.6 & 3.5 \\
\hline $\mathrm{CO}_{2}(\mathrm{mg} / \mathrm{L})$ & 1.2 & 1.2 & 1.2 & 1.2 \\
\hline $\mathrm{O}_{2}(\mathrm{mg} / \mathrm{L})$ & 9.0 & 9.0 & 9.0 & 6.0 \\
\hline $\mathrm{P}-\mathrm{PO}_{4}(\mathrm{mg} / \mathrm{L})$ & nt & nt & 1.0 & 1.5 \\
\hline $\mathrm{N}-\mathrm{NH}_{4}(\mathrm{mg} / \mathrm{L})$ & $\mathrm{nt}$ & nt & 0.25 & 0.50 \\
\hline $\mathrm{N}-\mathrm{NO}_{2}(\mathrm{mg} / \mathrm{L})$ & 0.35 & 0.35 & 0.53 & 0.28 \\
\hline $\mathrm{N}-\mathrm{NO}_{3}(\mathrm{mg} / \mathrm{L})$ & 0.14 & 0.21 & 0.14 & 0.14 \\
\hline $\mathrm{S}-\mathrm{SO}_{4}(\mathrm{mg} / \mathrm{L})$ & 0.30 & 0.48 & 0.48 & 0.46 \\
\hline $\mathrm{Ca}\left(\mathrm{mg} / \mathrm{L}\right.$ eq. $\left.\mathrm{CaCO}_{3}\right)$ & 28.0 & 26.0 & 38.0 & 20.0 \\
\hline $\mathrm{Mg}\left(\mathrm{mg} / \mathrm{L}\right.$ eq. $\left.\mathrm{CaCO}_{3}\right)$ & 14.0 & 14.0 & 12.0 & 10.0 \\
\hline Bahan organik total/Total organic matter $(\mathrm{mg} / \mathrm{L})$ & 34.08 & 35.08 & 33.18 & 35.08 \\
\hline Arus air/Water current $(\mathrm{m} / \mathrm{sec})$ & 0.80 & 0.65 & 1.27 & 0.25 \\
\hline
\end{tabular}

Berdasarkan perubahan atau gerakan kelompok ukuran ikan uceng menurut perubahan waktu dan stasiun pengamatan, maka diduga ikan uceng ini mulai mengadakan gerakan atau ruaya ke bagian hulu sungai pada pertengahan musim kemarau. Selanjutnya proses pematangan gonad hingga pemijahan ada di bagian hulu sungai, dan pada waktu akhir musim hujan anak-anak ikan uceng tersebut telah mencapai stadia yuwana dan bergerak ke hilir sungai.

\section{Ekologi Kali Lekso}

Kali Lekso merupakan anak Sungai Brantas yang sumber airnya berasal dari lereng Gunung Kelud. Kali ini termasuk sungai kecil pegunungan, dengan lebar perairan sungai saat air surut 4$10 \mathrm{~m}$ dan saat pasang berkisar antara 10-40 m dan panjang sungai mencapai 25 km. Perairan ini mempunyai arus yang cukup kuat $(0,3-1,3 \mathrm{~m} /$ det.). Pada saat air rendah dan kuat, arus yang terkuat terdapat di stasiun pengamatan III yang merupakan daerah penambangan batu kali (Gambar 5)
Suhu air relatif rendah $\left(25,5-26,0^{\circ} \mathrm{C}\right)$, oksigen terlarut tinggi (6-9,0 mg/L) dan kandungan karbondioksida Sungai ini mempunyai dasar perairan yang berbatu-batu dan airnya sangat jernih, bebas yang rendah (Tabel 2). Konsentrasi $\mathrm{P}-\mathrm{PO}_{4}$ dan $\mathrm{N}-\mathrm{NH}_{4}$ menunjukkan peningkatan ke arah hilir sungai, karena arus air makin ke hilir makin lemah sehingga aktivitas peng-

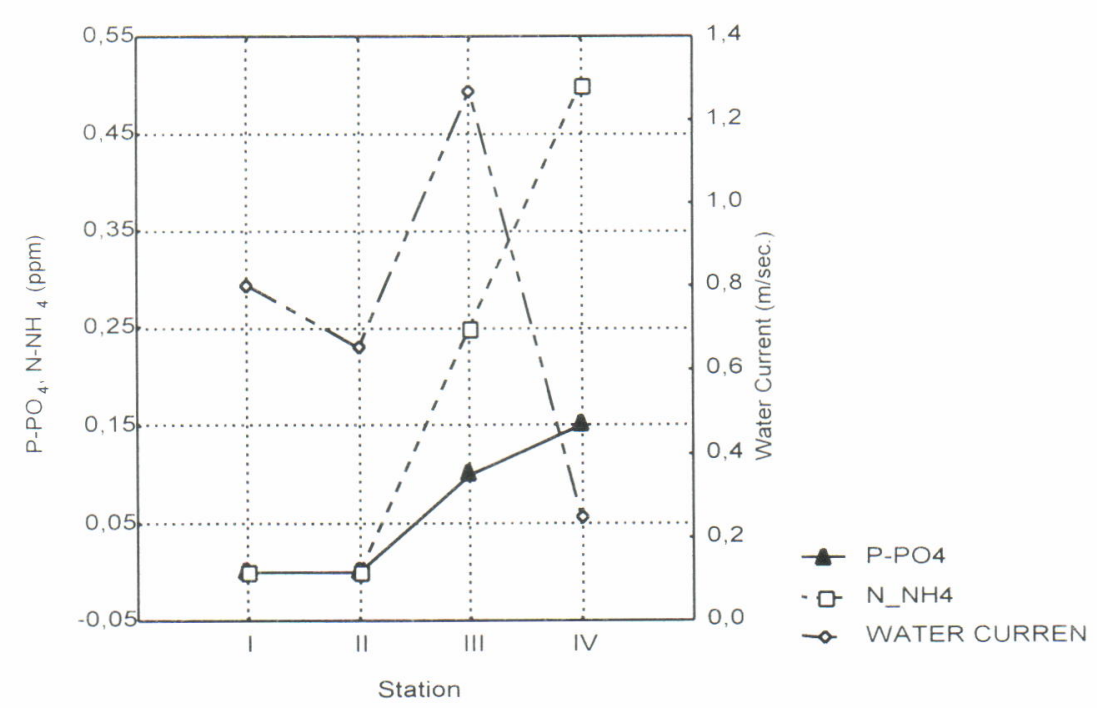

Gambar 5. $\quad \mathrm{P}_{-} \mathrm{PO}_{4}, \mathrm{~N}-\mathrm{NH}_{4}$ dan arus air menurut stasiun pengamatan Figure 5. $\quad \mathrm{P}_{-} \mathrm{PO}_{4}, \mathrm{~N}-\mathrm{NH}_{4}$ and water current by observation station 
uraian bahan organik menjadi lebih tinggi dan penumpukkan bahan organik dari bagian hulu (Gambar 5).

$\mathrm{Hal}$ tersebut juga disebabkan kandungan bahan organik total di perairan ini relatif tinggi (berkisar 33,2$35,1 \mathrm{mg} / \mathrm{L}$ ) jika dibandingkan anak-anak Sungai Citarum lokasi Saguling dan Cirata (Kartamihardja et al., 1987), dan di Sungai Sadang (Purnomo, 1991). Bahan organik tersebut diduga berasal dari daerah persawahan dan perkebunan, karena daerah aliran sungai Kali Lekso merupakan 60\% persawahan, 30\% perkebunan dan $10 \%$ perkampungan. Walaupun demikian, secara umum kualitas air di Kali Lekso cukup mendukung bagi kehidupan ikan dan organisme pakannya. Kualitas perairan tersebut relatif lebih baik dibandingkan kualitas air di Sungai Sadang (Purnomo, 1991), dan anak-anak Sungai Citarum lokasi Saguling dan Cirata (Kartamihardja et al., 1987)

Organisme produsen yang ada di Kali Lekso merupakan organisme perifiton termasuk genus Chaetophora, organisme yang hidup melekat dan menutupi permukaan batu-batuan di perairan tersebut. sedangkan jenis lainnya yang jarang ditemukan, adalah: Fragillaria, Surirella, Navicula dan Zygnema. Zoobenthos di perairan ini didominasi oleh larva caddisfly (Trichoptera), yaitu genus Platycentropus, sedangkan jenis makro zoobentos sangat jarang ditemukan, antara lain: Goniobasis dan Chironomus. Genus Chaetophora dan Platycentropus ini dimanfaatkan oleh komunitas ikan yang ada, khususnya Platycentropus sangat disukai oleh ikan yang ada, antara lain ikan uceng, tapelwatu, wader, dan paray.

Jenis ikan yang hidup di kali Lekso tersebut antara lain, ikan uceng, tapelwatu, wader, paray, kutuk, lele, dan belut. Sedangkan keragaman jenis ikan di Kali Lekso berdasarkan indeks Shannon-Wienner mempunyai nilai 1,61 (jumlah individu) dan 1,74 (biomassa), serta konstanta Motomura sebesar 0,45 (jumlah individu) dan 0,48 (biomassa). Hal tersebut berarti ekosistem perairan tersebut sangat dinamis atau ekosistem tersebut secara ekologi masih muda yang dicirikan dengan adanya dominasi yang sangat kuat, kompetisi tinggi dan stabilitas rendah. Dengan demikian keadaan tersebut sangat mudah sekali terjadi perubahan jika ekosistem tersebut mengalami tekanan. Berdasarkan nilai konstanta Motomura, perairan masih lebih stabil dibandingkan hasil penelitian Purnomo, et al. (1992) di Sungai Mahakam. Secara umum, komposisi jenis ikan di Kali Lekso didominasi ikan uceng baik berdasarkan jumlah individu maupun biomassa untuk bulan Juli, September, dan November (Gambar 6). Pada musim kemarau sampai awal musim hujan, ikan uceng cenderung tertangkap lebih banyak, dan sebaliknya pada musim hujan. Hal tersebut diduga bahwa pada musim kemarau volume air lebih sedikit dan arus air lebih lambat, serta ikan tersebut lebih banyak melakukan aktivitas (seperti aktivitas reproduksi), sehingga peluang tertangkap lebih besar

Pada umumnya, perairan sungai di daerah pegunungan didominasi jenis ikan karnivora dan predator (Inger \& Chin, 1962). Perairan Kali Lekso demikian juga, dari lima jenis yang dianalisis isi perutnya, empat di antaranya termasuk golongan ikan karnivora, yaitu: uceng, tapelwatu, wader, dan paray dengan nilai tingkat trofik berkisar antara 2,98-3,00 (Tabel 3). Sedangkan kutuk atau gabus gunung termasuk ikan predator.

Jenis pakan untuk golongan ikan karnivora ini didominasi oleh larva serangga (caddisfly), sedangkan perifiton sangat sedikit dimanfaatkan (Tabel 3). Kebiasaan pakan tersebut mirip dengan jenis ikan Rasbora argyrotaenia, Puntius binotatus, dan Nemachilus olivaceus di sungai-sungai Kalimantan Utara (Inger \& Chin, 1962), R. argyrotaenia di Waduk Widas (Tjahjo, 1987), dan $R$. argyrotaenia di Sungai Kapuas Vaas dalam Welcomme (1979). Ikan kutuk sangat banyak memanfaatkan ikan uceng sebagai makanannya. Ikan uceng yang mempunyai kelimpahan (220 ind $/ 100 \mathrm{~m}^{2}$ ) yang lebih besar dibandingkan ikan wader $\left(26\right.$ ind./100 $\left.\mathrm{m}^{2}\right)$ dan paray (35 ind./100

Tabel 3. Kebiasaan pakan, tingkat trofik dan luas relung pakan populasi ikan di Kali Lekso, Blitar

Table 3. Food habit, trophic level and niche breatdh of fish population in Lekso Stream, Blitar

\begin{tabular}{lccccc}
\hline \multirow{2}{*}{ Item } & \multicolumn{5}{c}{ Spesies ikan (Fish species) } \\
\cline { 2 - 5 } & uceng & tapelwatu & wader & paray & kutuk \\
\hline Ikan/Fish & - & - & - & - & 100.00 \\
Serangga/Insect & 25.00 & - & - & - & - \\
Larva serangga//nsect larva & 58.33 & 90.00 & 83.33 & 85.00 & - \\
Fitoplankton/Phytoplankton & 2.50 & - & 4.30 & - & - \\
Detritus & 14.17 & 10.00 & 12.37 & 15.00 & - \\
Tingkat trofik/Trophic level & 2.98 & 3.00 & 3.00 & 3.00 & 4.00 \\
Luas relung/Niche breatdh & 2.36 & 1.22 & 1.40 & 1.34 & 1.00 \\
\hline
\end{tabular}



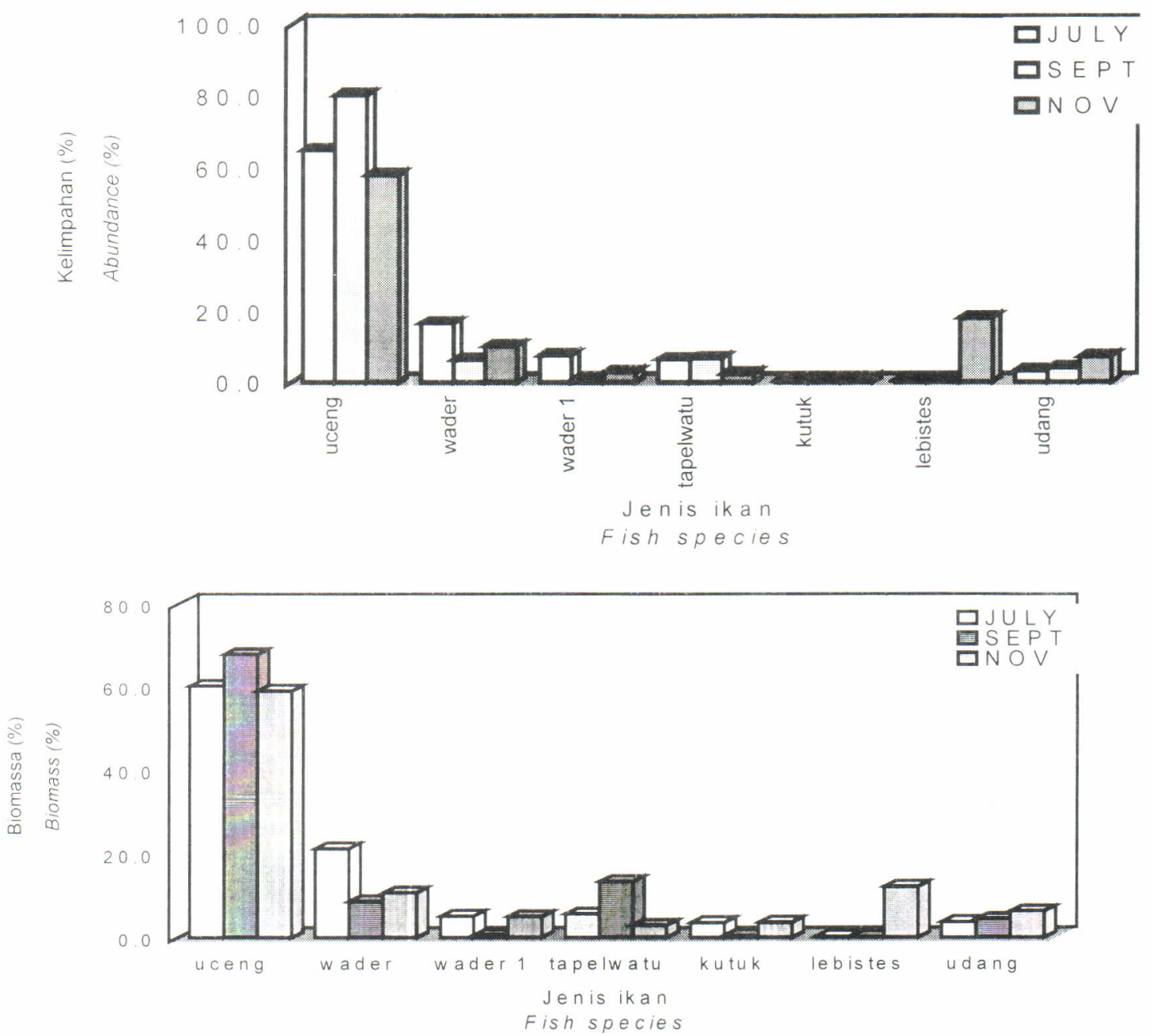

Gambar 6. Komposisi ikan di Kali Lekso

Figure 6. Fish composition of Lekso Stream

$\mathrm{m}^{2}$ ), diduga mempunyai peluang yang lebih besar tertangkap oleh kutuk dibanding ikan wader dan paray.

Luas relung pakan ikan di perairan ini relatif sempit, hal tersebut berhubungan dengan peran jenis ikan tersebut sebagai ikan karnivora dan predator yang cenderung lebih spesialis. Hal tersebut sama dengan hasil penelitian Tjahjo (1986) terhadap Rasbora argyrotaenia, $P$. binotatus, dan Channa striatus di Waduk Widas. Pakan utama ikan karnivora di perairan ini sama dan dikonsumsi dalam jumlah yang sangat besar, di mana ikan uceng mempunyai peluang yang lebih besar untuk muncul sebagai pemenang karena ikan ini mempunyai relung pakan yang lebih luas. Keunggulan ikan uceng ini terbukti dengan dominasinya yang sangat tinggi di perairan ini.

\section{KESIMPULAN}

Fekunditas total ikan uceng yang berukuran panjang antara $6,0-8,0 \mathrm{~cm}$ dengan bobot antara 2,12 -
5,55 g adalah berkisar 2.257-3.760 butir telur. Makin besar bobot ikan menunjukkan kecenderungan fekunditas total meningkat. Berdasarkan pola sebaran diameter telurnya, pola pemijahan sekali dalam satu tahun (musim) dengan lama waktu pemijahan relatif panjang.

Secara umum kualitas air di Kali Lekso cukup mendukung bagi kehidupan ikan dan organisme pakannya. Organisme produsen yang ada di Kali Lekso merupakan organisme perifiton termasuk genus Chaetophora, Fragillaria, Surirella, Navicula, dan Zygnema. Zoobentos di perairan ini didominasi oleh larva caddisfly (Trichoptera). Hasil analisis isi perut ikan menunjukkan ikan uceng, paray (Rasbora argyrotaenia), wader (Puntius binotatus), dan tapelwatu (Glyptothorax platypogon), dan kutuk (Channa gachua) termasuk predator. Empat jenis ikan karnivora tersebut bersifat spesialis dan mempunyai pakan utama yang sama, sehingga peluang terjadinya kompetisi yang tinggi. Secara umum, kualitas air di 
Kali Lekso cukup mendukung kehidupan ikan dan organisme pakannya.

\section{DAFTAR PUSTAKA}

Amanieu 1981. Models de distribution d'abondances cour de biometrie des dynamiquedes populations. Anima's Univ. Sc. Tech. Lnguedoc, Montpellier, 4: 64 p.

Caddy J.F. and G.P Sharp. 1986. An ecologycal framework for marine fishing investigations. FAO Fish. Tech. Pap., (283):153

Effendie, M.I. 1979. Metode Biologi Perikanan. Yayasan Dewi Sri. Bogor. 112pp.

Hespenheide, H.A., 1975. Prey characteristics and predator niche width, in Ecology and Evolution of Communites Cady. M.L. and J.M. Diamond (eds.) The Belknap Press of Marvard Univ. Press, London. p:158180

Inger, R.F. and Chin P.K., 1962. The freshwater fishes of North Borneo. Fielddiana: Zoology 45: 267 p.

Kartamihardja, E.S., A.S. Nastiti, Krismono, K. Purnomo dan A. Hardjamulia, 1987. Penelitian limno-biologis Waduk Saguling pada tahap pre-inundasi. Bull. Penel. Perik. Darat 6(3): 32-62.

Kottelat, M., A.J. Whitten, S.N. Kartikasari and S. Wirjoatmodjo. 1993. Freshwater Fishes of Western Indonesia and Sulawesi (Ikan Air Tawar Indonesia Bagian Barat dan Sulawesi). Periplus Editins Ltd. 293 $\mathrm{pp}$.
Magurran, A.E., 1988. Ecological Diversity and its Measurement. Princeton University Press, New Jersey. $179 \mathrm{pp}$.

Parel, C.P., G.C. Caldito, P.L. Ferrer, G.G Guzman, C.S. Sinsiaco and R.H. TAN, 1973. Sampling Design and Procedures. The Agricultural Development Council, New York.

Pauly, D. 1982. Studying single species dynamics in multispecies context In: D. Pauly and G.I. Murphy (eds.) Theory and management of tropical fisheries ICLARM Conference Proseeding, Manila,. pp: 33-70.

Purnomo, K., H.H. Suharto dan A. Sarnita, 1992. Struktur komunitas makrozoobentos di Sungai Mahakam di Kalimantan Timur. Bull. Penel. Perik. Darat 11(1): 12 18

Purnomo, K., 1991. Penelitian pendahuluan mutu lingkungan perairan Sungai Sadang. Bull. Penel. Perik. Darat 10(3):7-14.

Sparre, P. and S.C. Venema, 1992. Introduction to tropical fish stock assessment. Part I (Manual). FAO. Fisheries Technical Paper (rev.1). $376 \mathrm{p}$.

Tjahjo, D.W.H., 1986. Luas relung dan kompetisi pakan komunitas ikan di Waduk Bening, Jawa Timur. Bull. Penel. Perik. Darat 5(2): 69-77.

1987. Kebiasaan makan komunitas ikan di Waduk Bening, Jawa Timur. Bull. Penel. Perik. Darat 6(1): 59-64

Welcomme, R.L., 1979. Fisheries Ecology of Floodplain Rivers. Longman, London. 317 pp. 